\title{
Influence of bacteria on cell size development and morphology of cultivated diatoms
}

\author{
Miriam Windler, ${ }^{1 *}$ Dariia Bova, ${ }^{1}$ Anastasiia Kryvenda, ${ }^{2}$ Dietmar Straile, ${ }^{3}$ Ansgar Gruber ${ }^{1}$ and Peter G. Kroth ${ }^{1}$ \\ ${ }^{1}$ Pflanzliche Ökophysiologie, Fachbereich Biologie, Universität Konstanz, Konstanz, ${ }^{2}$ Abteilung Experimentelle \\ Phykologie und Sammlung von Algenkulturen (EPSAG), Göttingen, and ${ }^{3}$ Limnologisches Institut, Universität Konstanz, \\ Konstanz, Germany
}

\section{SUMMARY}

Vegetative cell division in diatoms often results in a decreased cell size of one of the daughter cells, which during long-term cultivation may lead to a gradual decrease of the mean cell size of the culture. To restore the initial cell size, sexual reproduction is required, however, in many diatom cultures sexual reproduction does not occur. Such diatom cultures may lose their viability once the average size of the cells falls below a critical size. Cell size reduction therefore seriously restrains the long-term stability of many diatom cultures. In order to study the bacterial influence on the size diminution process, we observed cell morphology and size distribution of the diatoms Achnanthidium minutissimum, Cymbella affiniformis and Nitzschia palea for more than two years in bacteria-free conditions (axenic cultures) and in cultures that contain bacteria (xenic cultures). We found considerable morphological aberrations of frustule microstructures in A. minutissimum and $C$. affiniformis when cultivated under axenic conditions compared to the xenic cultures. These variations comprise significant cell length reduction, simplification and rounding of the frustule contour and deformation of the siliceous cell walls, features that are normally found in older cultures shortly before they die off. In contrast, the xenic cultures were well preserved and showed less cell length diminution. Our results show that bacteria may have a fundamental influence on the stability of long-term cultures of diatoms.

Key words: axenic, cultivation, diatom, interaction, size reduction, xenic.

\section{INTRODUCTION}

Long-term cultivation of diatoms is often challenging, one reason for this is their characteristic cell cycle. The intracellular generation of new valves during vegetative cell division results in disparately sized daughter cells, of which only one retains the initial cell size, while the other daughter cell is smaller (Chepurnov et al. 2004). This effect, known as the MacDonald-Pfitzer rule (MacDonald 1869; Pfitzer 1871) causes a gradual reduction of the median cell size of a culture, with a few known exceptions: Eunotia minus (Kützing) Grunow (Geitler 1932), Adlafia minuscula var. muralis (Grunow) Lange-Bertalot (Locker 1950), Nitzschia paleacea Grunow, Nitzschia palea var. debilis (Kützing) Grunow (Wiedling 1948) and Phaeodactylum tricornutum Bohlin (Lewin et al. 1958; Martino et al. 2007). Recovery of the maximal (or initial) cell size takes place via auxospore formation, a process that mainly occurs after sexual reproduction (Chepurnov et al. 2004; Mann 2011). Once the cells reach a minimal size threshold, sexual reproduction can be triggered by external conditions such as light, temperature, presence of osmolytes and nutrient availability (Drebes 1977; Chepurnov et al. 2004). Many diatoms are not able to reproduce sexually in culture, for example, if the gametes produced within a clonal line are self-incompatible or if external triggers for sexual reproduction are missing. In such cultures, cell size diminution often continues and finally the cultures die (Geitler 1932; Chepurnov et al. 2004). For the long-term maintenance of diatom cultures it is therefore necessary to detect and optimize cultivation conditions, which retard or even prevent the cell size diminution. In this study we investigate the bacterial influence on the long-term stability of three different pennate diatoms, isolated from freshwater biofilms. In their natural habitats diatoms are usually associated with bacteria and the presence as well as the composition of the accompanying bacterial community may considerably impact the physiology of the algae. Bacteria are known to influence the formation of marine snow (Grossart et al. 2006), growth and production of extracellular polymeric substances (EPS) (Bruckner et al. 2008), reduce toxic compounds, for example

\footnotetext{
*To whom correspondence should be addressed.

Email: miriam.windler@uni-konstanz.de

Communicating editor: Kensuke Toyoda.
} 
hydrogen peroxide (Hünken et al. 2008), supply essential organic compounds like vitamins (Croft et al. 2005), stimulate secondary metabolite production like domoic acid in case of Pseudo-nitzschia multiseries (Hasle) Hasle (Bates et al. 1995; Kobayashi et al. 2009) or even act algicidal (Mitsutani et al. 2001; Kang et al. 2011). Analyses of bacterial assemblages in diatom cultures revealed dominance of Alpha-, Beta- and GammaProteobacteria and bacteria of the CytophagaFlavobacterium-Bacteroides (CFB) phylum (Schäfer et al. 2002; Kaczmarska et al. 2005; Sapp et al. 2007; Bruckner et al. 2008). In such cultures, the composition of the co-cultivated bacterial community depends on the composition of the bacterial community at the time of isolation, the diatom species itself and the cultivation conditions. It has been demonstrated that the bacterial composition in freshly isolated cultures differs from the associated bacterial community in situ and may change during extended cultivation (Sapp et al. 2007). In contrast, Schäfer et al. (2002) found the diatom-bacteria associations in several investigated cultures to be stable. Furthermore, they showed that bacterial communities of different diatom cultures are distinct in composition (Schäfer et al. 2002). Even the same diatom species may be associated with different bacterial communities, depending on the cultivation conditions (Kaczmarska et al. 2005).

In this study, we followed the cell size distribution and morphological changes of the benthic diatoms Achnanthidium minutissimum (Kützing) Czarnecki, Cymbella affiniformis Krammer and Nitzschia palea (Kützing) W. Smith in the presence and absence of their associated bacterial community for more than two years. We found that the average cell length and width as well as the frustule shape of two of the observed diatoms depend on the presence of bacteria. We further found evidence that the presence of bacteria in the culture slows down the overall size reduction. This study shows evidence that associated bacteria may be important for the long-term maintenance of clonal diatom cultures.

\section{MATERIALS AND METHODS}

\section{Isolation of diatoms}

Achnanthidium minutissimum isolate B-13, Cymbella affiniformis isolate B-16 and Nitzschia palea isolate B-01 were isolated in January 2009 from phototrophic, epilithic biofilms from the littoral zone of Lake Constance $\left(47^{\circ} 41^{\prime} \mathrm{N} ; 9^{\circ} 11^{\prime} \mathrm{E}\right.$, Germany). Detailed descriptions of isolation and purification from associated bacteria are described elsewhere (Windler et al. 2012). For isolation, the biofilm suspensions were streaked on agar plates containing a modified liquid Bacillariophycean Medium (BM) (Windler et al. 2012) and cul- tivated as described below. Single colonies were picked and transferred to liquid medium.

\section{Cultivation conditions}

Xenic and axenic diatom isolates were cultivated in liquid $\mathrm{BM}$ at standard cultivation conditions at $16^{\circ} \mathrm{C}$ in a $12: 12 \mathrm{~h}$ light : dark cycle and at a photon flux density of $20-50 \mu \mathrm{mol} \mathrm{m} \mathrm{m}^{-2} \mathrm{~s}^{-1}$. Cells were cultivated under non-shaking conditions in tissue culture flasks (Sarstedt, Newton, NC, USA). The strains were transferred to fresh media monthly, during the stationary phase. The cells were scraped from the bottom of the culture flask, and 15-20 $\mu \mathrm{L}$ culture medium containing approximately 15 000-20 000 cells (in case of A. minutissimum and $N$. palea) were transferred into $10 \mathrm{~mL}$ fresh BM. Backup cultures of xenic and axenic A. minutissimum cells were stored on agar plates with solid $\mathrm{BM}$ at $16^{\circ} \mathrm{C}$ with a photon flux density of $20-40 \mu \mathrm{mol} \mathrm{m} \mathrm{m}^{-2} \mathrm{~s}^{-1}$ and transferred to fresh plates every 2 months, additional backup cultures were stored at $8^{\circ} \mathrm{C}$ with a photon flux density of $0.5-2.0 \mu \mathrm{mol}$ $\mathrm{m}^{-2} \mathrm{~s}^{-1}$; these backup cultures were transferred to fresh plates every 3-6 months.

\section{Frustule preparation and identification of the diatom isolates}

For morphological identification and cell size determination of the diatom isolates, frustules were treated with $35 \%$ hydrogen peroxide at $95^{\circ} \mathrm{C}$ for $4 \mathrm{~h}$ and again with $10 \%$ hydrochloric acid at room temperature for $4 \mathrm{~h}$ and mounted in Naphrax (index $\mathrm{nD}$ 1.710; Euromex, Arnhem, Netherlands), roughly following a procedure described by the European Committee for Standardization (2003). For morphological identification, the purified frustules were observed using an Olympus BX51 microscope (Olympus Europe, Hamburg, Germany) at $1000 \times$ magnification and identified according to Krammer and Lange-Bertalot (1986, 1988, 1991) and Krammer (2002).

For analysis of the $18 \mathrm{~S}$ rDNA region, genomic DNA was extracted using a protocol from Murray and Thompson (1980) with slight modifications. Cell pellets of $7-8 \mathrm{~mL}$ cultures were pestled in $2 \times$ cetyltrimethylammonium bromide extraction buffer with $1 \%$ 2-mercaptoethanol and processed as described in Bruckner et al. (2008). Precipitation was increased using one volume of isopropanol. 18S rDNA fragments were amplified using the primers $5^{\prime}$-AAC CTG GTT GAT CCT GCC AGT-3' and 5'-TTG ATC CTT CTG CAG GTT CAG CTA-3' modified from Medlin et al. (1988). 18S rDNA clone libraries were established as described for $16 \mathrm{~S}$ rDNA libraries in Bruckner et al. (2008). 18S rDNA fragments were sequenced (GATC, Konstanz, Germany) 
and BLAST searches were performed against the National Center for Biotechnology Information database.

\section{Determination of cell length and width of diatom frustules}

The first frustule preparation of xenic diatoms was performed in April 2009, after a cultivation period of 3 months and the next preparation in August 2011 after an additional cultivation period of 28 months. Axenic diatoms were purified from xenic cultures in June 2009 and the respective frustules were also prepared in August 2011 after a cultivation period of 26.5 months. The diatom frustules were observed at 400$1000 \times$ magnification as described above. Images were taken with a Zeiss AxioCam MRm digital camera system (Carl Zeiss Microlmaging GmbH, Göttingen, Germany). Frustule sizes were determined with the digital image processing software Axio Vision LE (Carl Zeiss). Cell lengths were measured from pole to pole and cell widths at the widest part of the central area, 25 cells were measured from each sample.

\section{Temporal progression of cell length of A. minutissimum}

Cell lengths of xenic and axenic A. minutissimum cultures were examined from June 2009 to November 2011 at irregular intervals from images of live cells. Length measurements were conducted either by direct observation in the cultivation vessels with an inverted optical microscope (Axiovert $40 \mathrm{C}$, Carl Zeiss) or by observation of culture aliquots with an upright microscope (Olympus BX51, Olympus Europe, Hamburg, Germany). Length scales were determined individually for each of the used microscopes. Photographs were taken with Zeiss AxioCam MRc or MRm digital camera systems (Carl Zeiss) and analyzed with the digital image processing software Axio Vision LE (Carl Zeiss). Images of cultures taken after 150 (xenic and axenic), 305/306 (axenic) and 325 days (xenic) originated from cultures that were stained with crystal violet or $\mathrm{DiOC}_{6}$ (Molecular Probes, Life Technologies, Darmstadt, Germany), respectively, directly before the pictures were taken. Whenever possible, 25 cells per time point were used for measurements (exceptions: 14 axenic cells on day 131, 16 axenic cells on day 150,15 axenic cells on day 306 and 22 xenic cells on day 325). In order to test the influence of cultivation on solid medium on cell size reduction (compared to liquid cultivation), A. minutissimum cells were scraped from the backup cultures and transferred into liquid BM according to the test cultures. After one month cultivation under standard conditions, cell length was measured as described above. In the following we use the terms 'frustule length' for measurements of frustule material and 'cell length' for measurements of live cells.

\section{Growth of $A$. minutissimum and chlorophyll extraction}

To observe growth of xenic and axenic A. minutissimum, the progression of the chlorophyll concentration was measured in triplicates. $150 \mathrm{~mL}$ of $\mathrm{BM}$ was inoculated with $1 \times 10^{3}$ cells $\mathrm{mL}^{-1}$ and incubated at $16^{\circ} \mathrm{C}$ and $100 \mathrm{rpm}$ with a photon flux density of $50 \mu \mathrm{mol} \mathrm{m} \mathrm{m}^{-2} \mathrm{~s}^{-1}$ and a light : dark cycle of 12:12 h. For each time point chlorophyll was extracted from an aliquot of $1 \mathrm{~mL}$ diatom culture by addition of a mixture of $5 \%$ methanol and $95 \%$ acetone to the cell pellet. Chlorophyll concentrations were determined using the equation for diatoms, chrysomonads and brown algae according to Jeffrey \& Humphrey (1975). The growth rates $(\mu)$ of the cultures were calculated during the exponential growth phase of the two cultures as:

$$
\mu=\left(\ln \left(\mathrm{Ch}_{\mathrm{t} 2}\right)-\ln \left(\mathrm{Ch}_{\mathrm{t} 1}\right)\right) /\left(\mathrm{t}_{2}-\mathrm{t}_{1}\right)
$$

with the chlorophyll concentrations $\mathrm{ChI}_{\mathrm{t}_{1}}$ and $\mathrm{Chl}_{\mathrm{t}_{2}}$ at the beginning $\left(t_{1}\right)$ and at the end $\left(t_{2}\right)$ of the exponential phase. The exponential growth phase lasted from day 11 to 22 in the axenic, and from day 4 to 18 in the xenic culture.

\section{Statistical analysis}

We compared the cell dimensions (length, width and length-to-width ratio) of diatom frustules of the xenic cultures in 2009, 2011 and of the axenic cultures in 2011 using analysis of variance (ANOVA) and Tukey's honestly significant difference (HSD) posthoc tests. For A. minutissimum the temporal progression of mean cell length was analyzed for the xenic and axenic cultures with regression models using time since the start of the experiment as an independent variable. We further used a $t$-test to analyze differences in cell size of living cells of A. minutissimum. In addition, we used ANOVA and Tukey's HSD to test for differences in cell length between all liquid and backup cultures of $A$. minutissimum in 2012. Statistical analyses were performed in $R$ ( $R$ Development Core Team 2011).

\section{RESULTS}

\section{Identification of the diatom isolates}

At the beginning of the experiments in 2009 the diatom isolates were identified using morphological criteria and 18S rDNA sequence analyses. Isolate B-13 exhibited typical features of Achnanthidium minutissimum (Krammer \& Lange-Bertalot 1991). The valves were linear-lanceolate with broadly rostrate ends. The axial 
Achnanthidium minutissimum

2009 xenic

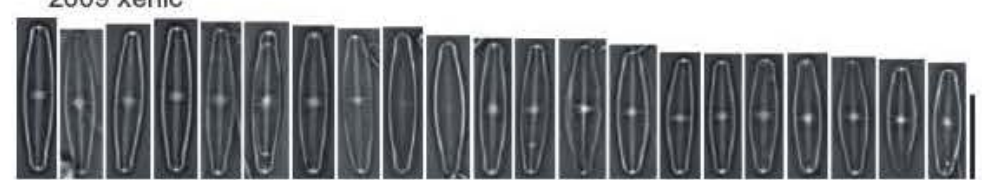

2011 axenic
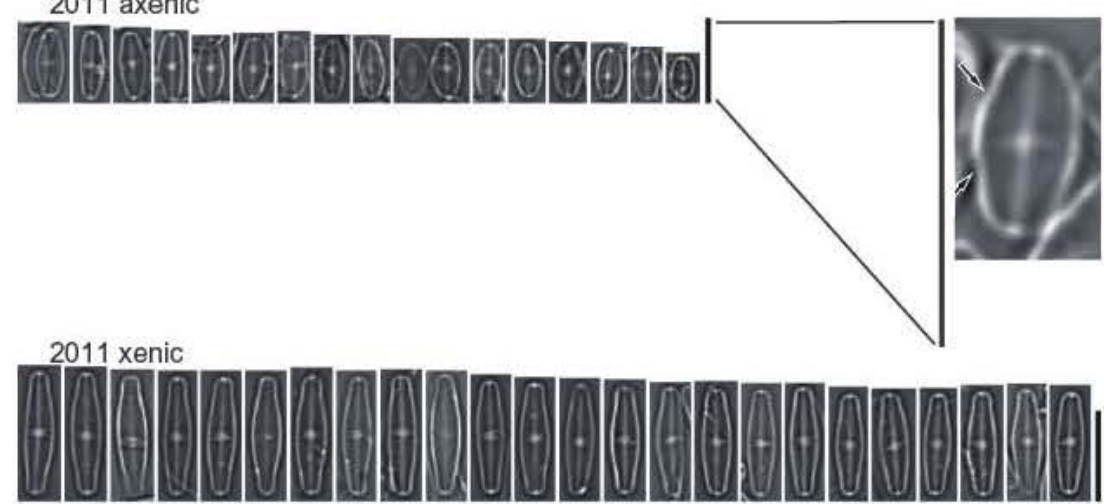

Cymbella affiniformis

2009 xenic

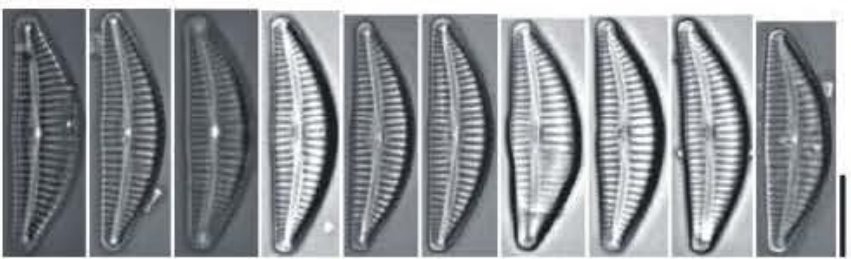

2011 axenic

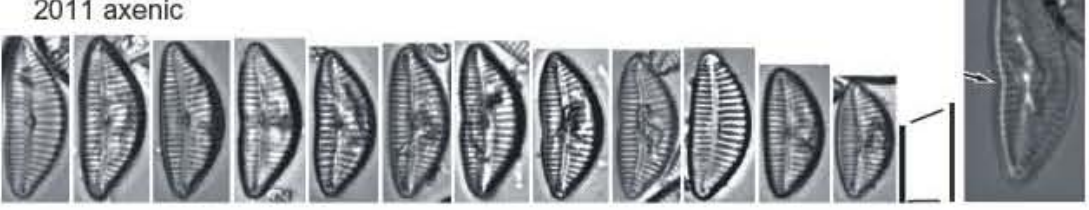

2011 xenic

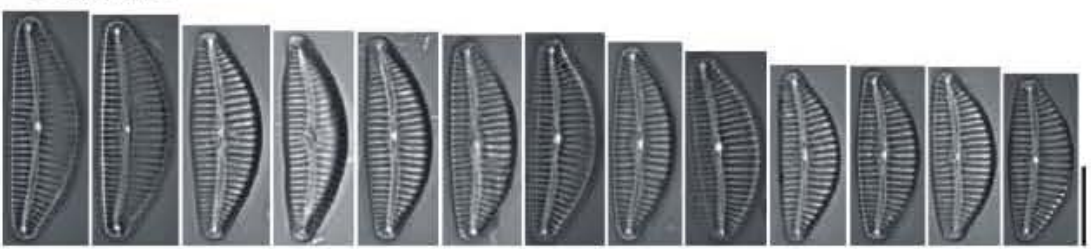

Fig. 1. Frustules of Achnanthidium minutissimum in April 2009 and after cultivation in axenic and xenic state in August 2011. Arrows mark parts of the frustule deformation. Scale bars represent $10 \mu \mathrm{m}$.

Fig. 2. Frustules of Cymbella affiniformis in April 2009 and after cultivation in axenic and xenic state in August 2011. Arrow marks the concave ventral margin. Scale bars represent $10 \mu \mathrm{m}$. area was narrow, linear or slightly lanceolate. The central area was formed by one or two shortened and more broadly spaced striae. The central area was variable and present on both sides or only on the one side of the valve and never formed a stauros (Fig. 1). The BLAST results of the $18 \mathrm{~S}$ rDNA fragment of isolate B-13 showed high similarities of $99 \%$ with the database entry of $A$. minutissimum (GenBank AM502032).

Based on the morphological characters we consider the isolate B-16 to represent Cymbella affiniformis (Krammer 2002). The valves were moderately dorsiventral, lanceolate, the dorsal margin was strongly convex and the ventral margin was slightly convex. The ends were subrostrate to rostrate and narrowly rounded (Fig. 2). Sequence analysis of B-16 showed high similarities of $99 \%$ with Cymbella affinis Kützing (AM502018/AM502009) and Cymbella excisa Kützing (JN790273), however, there is no database entry for C. affiniformis.

Isolate B-01 showed all characters of Nitzschia palea as described in Krammer and Lange-Bertalot (1988). Two forms were present in this culture, 
Fig. 3. Frustules of Nitzschia palea in April 2009 and after cultivation in axenic and xenic state in August 2011. The culture consisted of $N$. palea f. major with longer cells (large morphotype) and $N$. palea with shorter cells (small morphotype) at the beginning of the experiment in 2009. In 2011 the xenic and axenic cultures contained only cells of the smaller morphotype. Scale bars represent $10 \mu \mathrm{m}$.

\section{Nitzschia palea}

2009 xenic

large morphotype
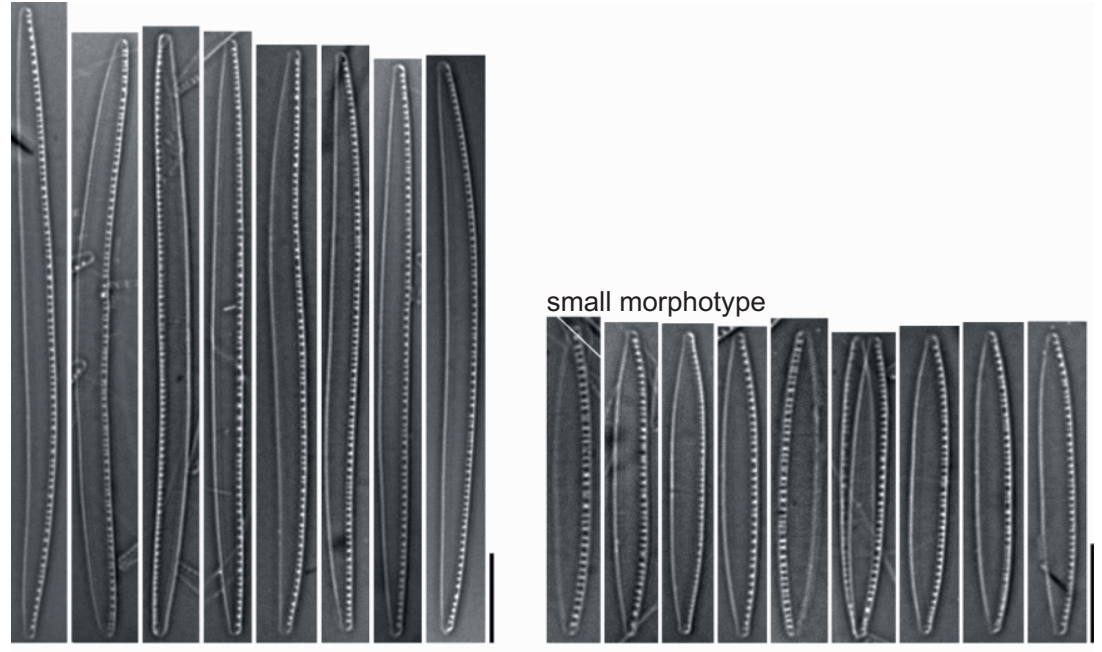

2011 axenic

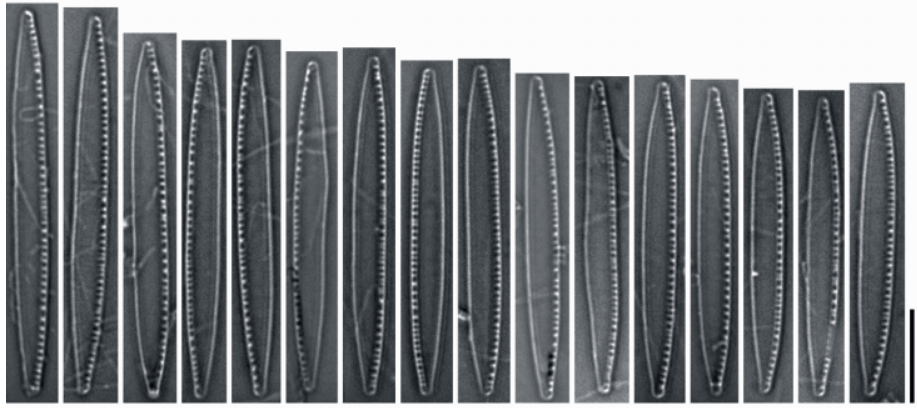

2011 xenic

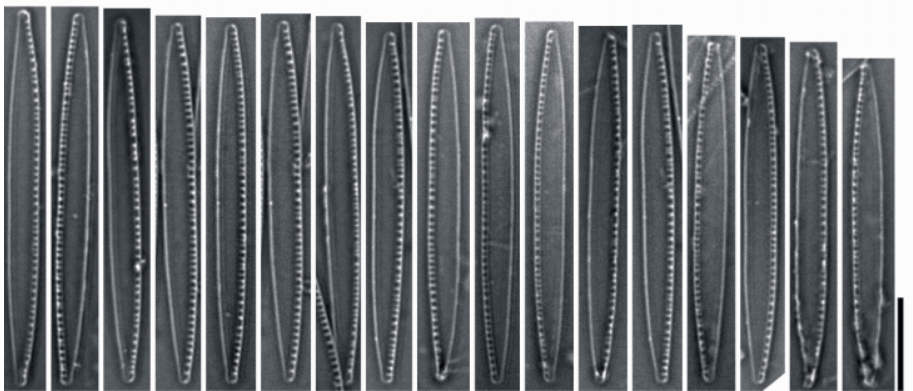

N. palea f. major Rabenhorst, which has considerably longer cells, and N. palea with shorter cells. The valves were linear-lanceolate (smaller morphotype) to linear (larger morphotype) and the valve margins at the center were linear (larger morphotype) or slightly convex (smaller morphotype). The poles were rostrate, subrostrate or subcapitate. Striae were not visible under the light microscope. Fibulae were more or less squarelike. The distance between the fibulae was irregular, but the central pair of fibulae was more widely separated than the others (Fig. 3). The BLAST results of the $18 \mathrm{~S}$ rDNA fragments of isolate B-01 coincide with the mor- phological identification, exhibiting 100\% similarity with N. palea (AJ867008/AJ867006/AJ867001).

\section{Cell size and frustule morphology of axenic versus xenic diatom cultures}

Figure 4 gives an overview of the dates of diatom isolation, purification from associated bacteria and sampling for length measurements. A. minutissimum exhibited considerable differences in frustule morphology when cultivated with or without bacteria in liquid medium (Fig. 1). Frustules of xenic cells retained 


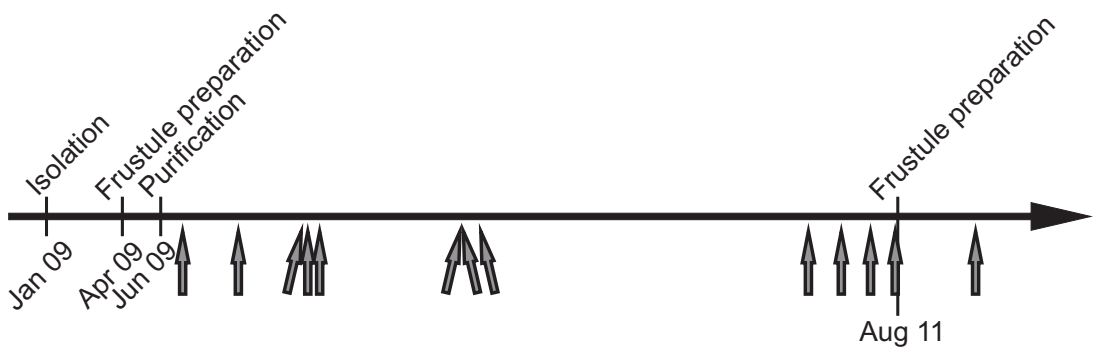

Fig. 4. Timescale of diatom isolation, purification and frustule preparation. Small arrows mark points of length measurements of Achnanthidium minutissimum live cells.

Table 1. Mean values of frustule length, width and length-to-width ratio of Achnanthidium minutissimum, Cymbella affiniformis and Nitzschia palea in April 2009 and after long-term cultivation under xenic and axenic conditions in August 2011

\begin{tabular}{|c|c|c|c|c|c|c|}
\hline & & Xenic 2009 & Xenic 2011 & Ratio $(\%) \dagger$ & Axenic 2011 & Ratio $(\%) \dagger$ \\
\hline \multirow[t]{3}{*}{ A. minutissimum } & Length $(\mu \mathrm{m})$ & $16.52( \pm 1.59)$ & $13.84( \pm 0.6)$ & -16.2 & $7.64( \pm 0.76)$ & -53.8 \\
\hline & Width $(\mu \mathrm{m})$ & $4.16( \pm 0.24)$ & $3.93( \pm 0.2)$ & -5.5 & $3.62( \pm 0.18)$ & -13 \\
\hline & Length : width & 3.98 & 3.53 & & 2.11 & \\
\hline \multirow[t]{3}{*}{ C. affiniformis } & Length $(\mu \mathrm{m})$ & $30.02( \pm 0.8)$ & $26.6( \pm 3)$ & -11.4 & $20.14( \pm 1.51)$ & -32.9 \\
\hline & Width $(\mu \mathrm{m})$ & $8.6( \pm 0.39)$ & $9.42( \pm 0.54)$ & +9.5 & $8.67( \pm 0.4)$ & n.s. \\
\hline & Length : width & 3.5 & 2.83 & & 2.33 & \\
\hline \multirow[t]{3}{*}{ N. palea } & Length $(\mu \mathrm{m})$ & $\begin{array}{l}68.59( \pm 2.46)^{\mathrm{a}} \\
31.74( \pm 0.54)^{\mathrm{b}}\end{array}$ & $40.06( \pm 1.89)$ & -41.6 & $36.23( \pm 2.13)$ & -47.2 \\
\hline & Width $(\mu \mathrm{m})$ & $\begin{array}{l}4.35( \pm 0.68)^{\mathrm{a}} \\
4.04( \pm 0.31)^{\mathrm{b}}\end{array}$ & $3.78( \pm 0.1)$ & -13.1 & $3.68( \pm 0.17)$ & -15.4 \\
\hline & Length : width & $\begin{array}{l}16.08^{\mathrm{a}} \\
7.9^{\mathrm{b}}\end{array}$ & 10.6 & & 9.87 & \\
\hline
\end{tabular}

†describes the percentile differences in frustule length and width compared to the original sizes in 2009. Cell lengths and widths of $N$. palea measured in 2011 were thereby compared to those of $N$. palea f. major (large morphotype). n.s. reveals no significant differences. ${ }^{\mathrm{a}} \mathrm{N}$. palea f. major, ${ }^{\mathrm{b}} \mathrm{N}$. palea small morphotype. Standard deviation is given in parentheses.

the typical features of $A$. minutissimum even after a long period of cultivation (Krammer \& Lange-Bertalot 1991). However, in our axenic A. minutissimum culture, the valve outline of the cells was rhombic to elliptic, with the ends broadly rounded and sometimes slightly protracted. The valves seemed partly to be thinner and deformed compared to valves of the original xenic culture. After more than two years in culture, the length and width of the xenic diatom cells were slightly shorter compared to the original values (Table 1, Fig. 5). In contrast, the average frustule length and width of the axenic diatom culture were considerably more reduced after a comparable cultivation period. The length-to-width ratio in the axenic culture was substantially lower compared to the xenic A. minutissimum cultures (Table 1, Fig. 5). As a result, we observed a slight reduction of frustule size of A. minutissimum of $16.2 \%$ in length and $5.5 \%$ in width in the presence of bacteria but an extensive reduction of $53.8 \%$ in length and $13 \%$ in width in the axenic culture after more than two years of cultivation. All observed differences in frustule length and width between xenic and axenic cultures at different time points are statistically significant (Fig. 5).
No significant differences of cell length of live cells between xenic and axenic cultures of $A$. minutissimum were observed at the beginning of the experiment in June 2009 (Fig. 6, P>0.05, see Appendix S1 for example measurements). The xenic culture thereby exhibited a mean cell length of $13.65 \pm 1.22 \mu \mathrm{m}$ and the axenic culture immediately after purification had a mean cell length of $13.06 \pm 1.21 \mu \mathrm{m}$. This demonstrates that the applied purification methods had no direct influence on the cell length of $A$. minutissimum. The cell length of the axenic culture decreased $(n=10, \mathrm{t}=-4.8, P<0.01)$ to $9.68 \pm 0.97 \mu \mathrm{m}$, whereas the cell length of the xenic culture did not decline $(n=10, \mathrm{t}=-1.0, P=0.32)$ and remained at $13.8 \pm 1.05 \mu \mathrm{m}$. Interestingly, the xenic culture abruptly developed larger cells with a mean length of $15.9 \pm 0.82 \mu \mathrm{m}$ after 325 days with a significant difference to cell length of the previous measurement after 150 days $(P<0.05)$.

During the long-term cultivation of xenic and axenic A. minutissimum cultures in liquid BM (three parallel axenic cultures and two parallel xenic cultures), it was occasionally necessary to re-inoculate the axenic liquid medium cultures from backup cultures kept on solid $\mathrm{BM}$ at $16^{\circ} \mathrm{C}$ and at $8^{\circ} \mathrm{C}$. To exclude the possibility that 
Fig. 5. Frustule length, width and length-to-width ratio of Achnanthidium minutissimum, Cymbella affiniformis and Nitzschia palea in the xenic cultures in April 2009 (x09) and August 2011 (x11) and in the axenic cultures in August 2011 (ax11). For $N$. palea dimensions of the large (I) and small (s) morphotypes observed in the xenic culture in April 2009 (x09 l/s) are shown. Widths of the large and small morphotype completely overlap. Results of ANOVA and Tukey's HSD testing are shown below each chart. The first line points to significant $(P<0.05)$ differences between the cultures based on post-hoc tests (Tukey's HSD, means not differing share the same letter). The second line gives the F-value, degrees of freedom and significance level.
Achnanthidium minutissimum Cymbella affiniformis

Nitzschia palea
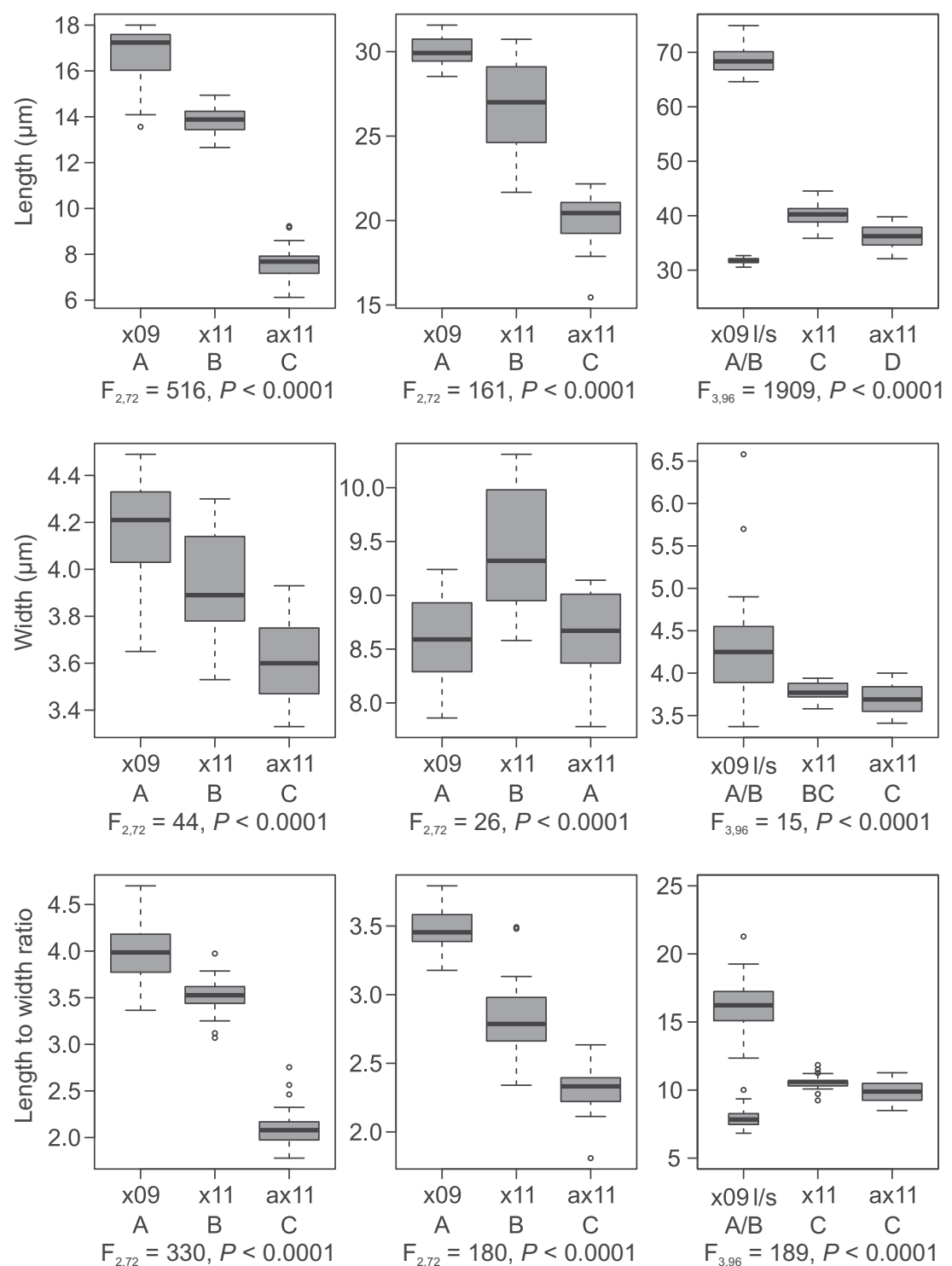

the cell size reduction of the axenic diatom culture was induced by such changes between cultivation on solid medium versus liquid medium or by the lower cultivation temperature of the backup cultures, we measured and compared cell lengths of all existing xenic and axenic $A$. minutissimum cultures at the end of the experiment in February 2012. Interestingly, cells of A. minutissimum, when cultivated at $16^{\circ} \mathrm{C}$ on solid diatom medium, in our hands became considerably smaller compared to those that were cultivated in liquid medium (Fig. 7). Nevertheless, in each observed case the xenic cells were significantly longer than the axenic ones, independent from the type of medium used for cultivation. This proves that cultivation on solid medium alone does not explain the differences in length between xenic and axenic $A$. minutissimum and thus the observed differences have to be attributed to the presence or absence of bacteria.

To evaluate possible differences in the numbers of cell divisions between xenic and axenic cultures, the temporal progression of the chlorophyll concentration of these cultures was measured (Fig. 8). The xenic culture had a high potential to form cell aggregates, whereas the axenic culture grew completely suspended. This condition made it impractical to determine the growth rate by cell counting methods and we therefore chose chlorophyll concentration as a measure for growth. Logarithmic scale of the growth curves (not shown) showed a prolonged lag-phase of 11 days for the axenic culture, while the xenic culture entered the exponential phase earlier after 4 days of cultivation. A. minutissimum exhibited a slightly higher growth rate 


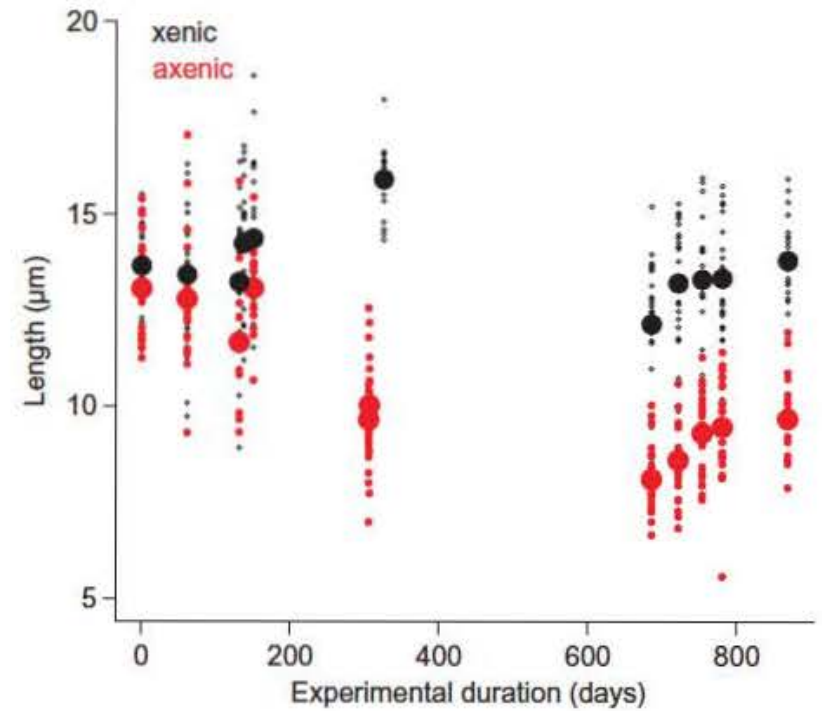

Fig. 6. Temporal progression of cell length of xenic and axenic Achnanthidium minutissimum. Cell length was determined for live cells from June 2009 till November 2011. Red, axenic culture; black, xenic culture; small dots, individual measurements; large dots, arithmetic means.

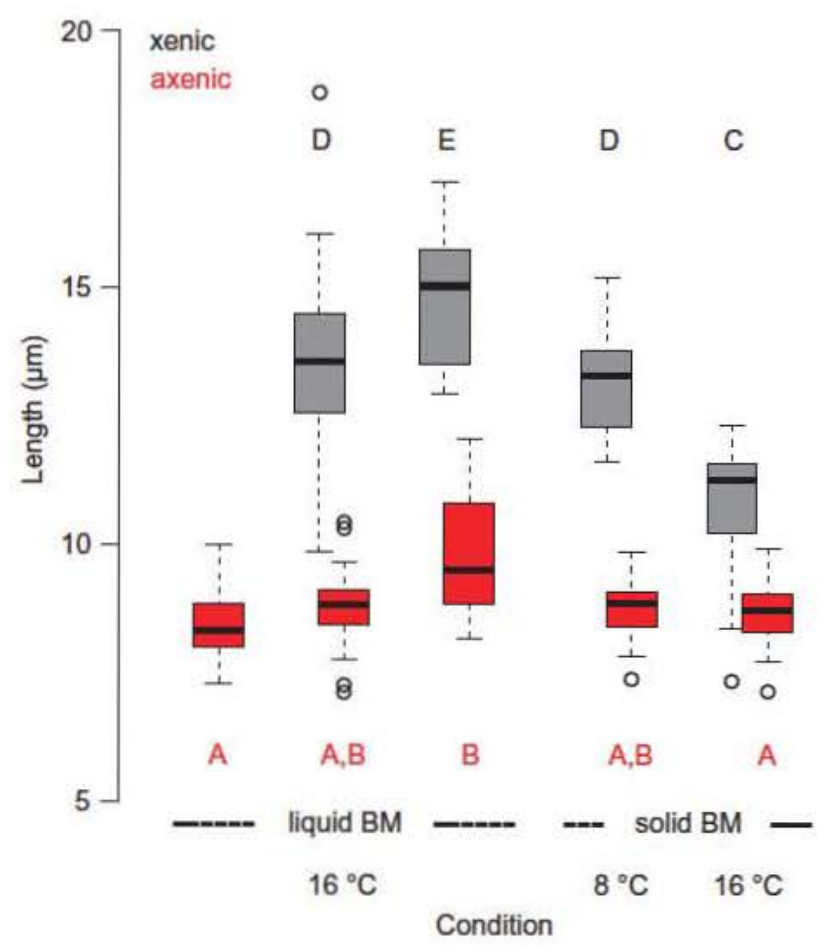

Fig. 7. Cell lengths of liquid and backup cultures of Achnanthidium minutissimum cultivated under different conditions in February 2012. Grey, xenic cultures; red, axenic cultures. Significant differences were denoted with different letters. $P$-values $>0.05$ were determined as the cut-off for significance.

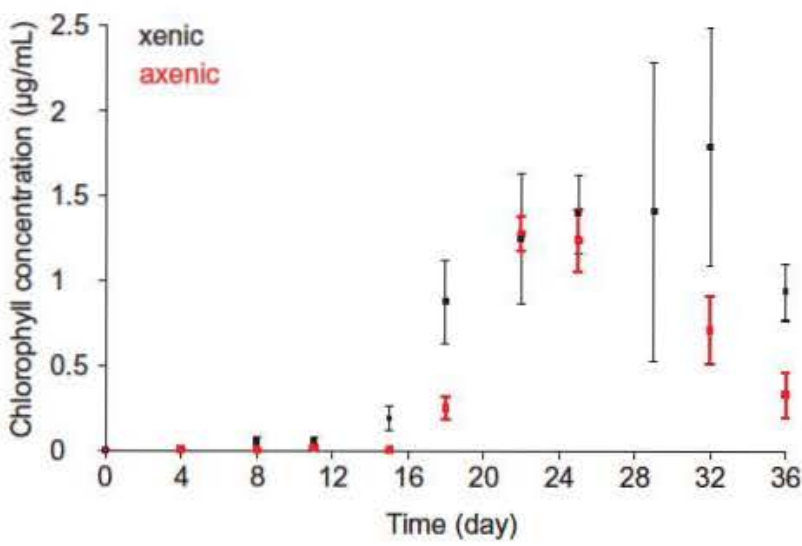

Fig. 8. Growth of Achnanthidium minutissimum in xenic (black) and axenic state (red). Both cultures reached similar chlorophyll concentrations in the stationary phase $\left(1.25 \pm 0.39 \mu \mathrm{g} \mathrm{mL}^{-1}\right.$ in the xenic culture, $1.28 \pm 0.1 \mu \mathrm{g} \mathrm{mL}^{-1}$ in the axenic culture after 22 days of cultivation). High error bars in the late stationary phase are attributed to the formation of cell aggregates.

of 0.4 days $^{-1}$ in the axenic state compared to 0.31 days $^{-1}$ in the xenic state. This corresponds to a doubling time of 1.73 days in the axenic and 2.21 days in the xenic diatom culture. Both cultures reached similar chlorophyll concentrations in the stationary phase $\left(1.25 \pm 0.39 \mu \mathrm{g} \mathrm{mL}^{-1}\right.$ in the xenic, $1.28 \pm 0.1 \mu \mathrm{g} \mathrm{mL}^{-1}$ in the axenic culture after 22 days of cultivation). In the late stationary phase, after 25 days of observation, the chlorophyll concentration of the axenic culture declined, whereas that of the xenic culture remained stable for a longer time. The xenic culture formed cell aggregates in the course of the stationary phase resulting in high standard deviations of chlorophyll measurements.

In all studied xenic C. affiniformis cultures the frustules exhibited typical morphological characteristics as described in Krammer (2002) (Fig. 2). Apart from a decreased length-to-width ratio, frustules of cells cultivated in xenic conditions exhibited no major differences to frustules of cells harvested at the beginning of the experiment (Fig. 2). In the axenic culture, however, we frequently found cells with a concave ventral margin. Valve ends were slightly protracted and acutely rounded. After the cultivation period of about 28 months the frustule lengths of the xenic diatom culture showed a relatively broad distribution but a significant shift of $11.4 \%$ to smaller lengths compared to the original value in April 2009 (Table 1, Fig. 5). An extensive reduction of frustule length of about $33 \%$ was also observed in the axenic diatom culture. Frustule width persisted in case of the axenic culture, but increased significantly for the xenic diatom culture. In both cases a significant decrease of the length-to-width ratio was observed compared to the original value in April 2009. 
At the beginning of the experiment $N$. palea showed all characters described in Krammer and LangeBertalot (1988) (Fig. 3). The ratio between the large and small morphotypes in the cultures was 39:61. After more than two years in culture, frustules which originated from xenic or axenic cultures exhibited no visible differences in microstructure. All cells were uniform and corresponded to the $N$. palea smaller morphotype description. The frustules of xenic and axenic cultures were significantly shorter compared to those of $N$. palea f. major in 2009 , but significantly longer than $N$. palea smaller morphotype in 2009 (Table 1, Fig. 5). Therefore we consider $N$. palea f. major as parental for the cultures observed in 2011. N. palea exhibited a significantly shorter length when cultivated without bacteria compared to the xenic culture. Frustule width of xenic and axenic cultures also decreased during the experiment but did not differ significantly from each other in 2011. Length-to-width ratio decreased remarkably in both cultures in 2011 when compared to $N$. palea f. major in 2009.

\section{DISCUSSION}

Changes of cell size and morphology of diatoms during their life cycle have been known for a very long time (MacDonald 1869; Pfitzer 1871; Geitler 1932). These changes are crucial for the long-term stability of many diatom cultures because small cells, if auxosporulation is omitted, often become continuously smaller resulting in a loss of the culture. Furthermore, as we know from our own experience, very small cells may show a different physiological behavior and thus compromise the reproducibility of experiments conducted with the strain. For example, stalk formation of Achnanthes longipes C. Agardh is strongly reduced in small cells compared to large cells (von Stosch 1965). It is thus very important to develop methods that avoid or reduce cell size diminution of diatoms. One strategy is, if feasible, the maintenance of clones of the opposite mating type to induce sexual reproduction (Chepurnov et al. 2004). However, sexual reproduction will change the gene pool of the culture and for many genetic studies clonal cultures are essential. Long-term maintenance of diatoms via standardized cryopreservation therefore might represent an ideal solution but only a few protocols for individual freshwater species are already available (McLellan 1989; Buhmann et al. 2013). In this study we observed the influence of associated bacteria on the long-term maintenance of three pennate diatom cultures and our results show that in two of the three investigated diatom species the axenic culture exhibited considerably shorter cells and aberrations in frustule morphology, whereas the cell length and frustule shapes were quite preserved in the xenic cultures.
The strongest effect of bacteria on cell size preservation was observed for $A$. minutissimum where cell length of the axenic culture decreased by more than half, whereas in the xenic culture just a slight reduction was observed (Table 1, Fig. 5). Comparing the original length of frustules and live cells in April and June, the major length decrease of the xenic A. minutissimum culture happened at the beginning of the experiment, soon after isolation of the diatom. Afterwards the cell length of the xenic culture remained around $13.8 \mu \mathrm{m}$, both when measuring frustules or live cells. However, it has to be taken into account that there may be slight differences between the cell lengths that were determined either by frustule or live cells measurements. For example, the axenic A. minutissimum culture showed a mean frustule length in August 2011 of $7.64 \pm 0.76 \mu \mathrm{m}$ (frustule measurement), compared to $9.63 \pm 1.00 \mu \mathrm{m}$ (live cells measurement). The measurement of frustules may be more accurate than the measurement of live cells. One reason could be that the xenic A. minutissimum cells form a capsule of EPS which makes it even harder to define the correct cell border and due to the EPS matrix the cells were not always oriented completely planar to the microscope slide. Measurements of live cells can therefore indicate a trend; the absolute cell length values must be determined by means of frustules. According to Figure 6, the cell lengths of the xenic and axenic A. minutissimum cells may be slightly increased at the end of the experiment. Thus, the algae exhibited mean cell lengths of $12.15 \pm 1.69 \mu \mathrm{m}$ after 685 days and $13.8 \pm 1.05 \mu \mathrm{m}$ after 868 days in the xenic and $8.12 \pm 0.90 \mu \mathrm{m}$ after 685 days and $9.68 \pm 0.97 \mu \mathrm{m}$ after 868 days in the axenic culture. However, cell lengths of the parallel cultures of $A$. minutissimum slightly differ among themselves (Fig. 7). The axenic cultures thereby range from $8.49 \pm 0.72 \mu \mathrm{m}$ to $9.69 \pm 1.15 \mu \mathrm{m}$ and the xenic cultures from $13.61 \pm 1.85 \mu \mathrm{m}$ to $14.83 \pm 1.30 \mu \mathrm{m}$. Thus, we attribute those observed cell length differences to variances within the single cultures rather than to an actual increase. The same pattern of a differential frustule length decrease between the xenic and axenic cultures was also observed for $C$. affiniformis. It must be noted here, that the identification results for this isolate were controversial. According to Krammer and Lange-Bertalot (1986), this strain should be identified as C. affinis. However, according to Krammer (2002) the strain represents neither $C$. affinis due to the absence of a central area, nor $C$. excisa due to the presence of two stigmas; instead, the characters of the strain are in agreement with the description for $C$. affiniformis. Interestingly, although the cell length reduction was not prominent in the xenic $C$. affiniformis culture, the cells increased significantly in width. The ability to increase cell width to counteract a decrease of the cell volume 
was already mentioned by Geitler (1932), but only in very small cells. It seems that $C$. affiniformis attempts to regulate the decrease of volume by broadening the cell width in early stages of the length diminution process. The cell width increase was not observed in the axenic cultures. However, it was possibly falsified by a concave ventral margin that was found in some cells of this culture. Axenic A. minutissimum and C. affiniformis showed aberrations in frustule morphologies that were not observed in the xenic cultures. Changes in frustule shape of pennate diatoms during size reduction have been known for a long time (Geitler 1932) and correlate with our observation of decreasing length-to-width ratio, simplification and rounding of the frustule contour and weakening of the frustules. Atypical changes of the morphology in axenic state were also reported for the green algae Ulva linza Linnaeus, here the normal morphology could be restored by adding specific bacteria to the alga (Marshall et al. 2006). The authors speculate that nitrogen supply, hormone production and production of secondary metabolites by the bacteria might explain the bacterial influence on the morphology of the alga. To which extent the observed aberrations are directly contributed to the absence of bacteria or to the normal shape changes, which usually occur during the diminution process, remained uncertain. The $N$. palea culture consisted of two cell types in 2009, a large and a small morphotype. The cultures are clonal as we isolated the cells by picking single colonies on agar plates, thus the two cell types must have developed from each other, either by auxosporulation or by abrupt size reduction. The large cells show irregular shapes or bends along the apical axis, which are also known for initial cells of other Nitzschia species (Geitler 1928; Trobajo et al. 2006). It is therefore conceivable that the long cells developed from the small morphotype by auxosporulation. Compared to the other two diatom species, the differences in cell length between xenic and axenic in 2011 are not that remarkable in the $N$. palea culture.

We can currently only speculate about the underlying mechanisms bacteria use to be able to influence the cell size and morphology of $A$. minutissimum and C. affiniformis, but the following scenarios are theoretically conceivable: (a) Bacteria may influence the frequency of mitotic cell division; (b) Bacteria may influence sexual reproduction; (c) Bacteria may influence other processes like vegetative cell enlargement or abrupt cell size reduction; (d) Bacteria may improve cell wall synthesis of the diatoms.

Bacteria could possibly influence the frequency of mitotic cell division and, if the culture is able to reproduce sexually, consequently the frequency of auxosporulation. An increase of vegetative cell divisions in this case might enhance the frequency of auxosporulation, because the critical size threshold for auxosporulation is attained faster, resulting in a culture of mostly large cells. If the culture is not capable of sexual reproduction, a decrease of the division rate in the xenic culture could be another possible explanation. In our growth experiments with $A$. minutissimum, the axenic culture exhibited a longer lag phase and a shorter cell doubling time compared to the xenic culture; both cultures had similar chlorophyll concentrations in the stationary phase. This suggests similar cell densities of both cultures in the stationary phase and consequently similar cell division numbers. The shorter cell lengths and altered morphology observed in axenic cultures can therefore not simply be attributed to different numbers of mitotic cell divisions during vegetative growth.

Direct stimulation of sexual reproduction of diatoms by bacteria was already reported by Nagai et al. (1994, 1999) and Nagai and Imai (1998). They found that spermatogenesis of the centric diatom Coscinodiscus wailesii Gran \& Angst is induced by bacteria, a hint that bacteria indeed might externally trigger sexual reproduction and auxosporulation of diatoms. Sexual reproduction and accompanied auxosporulation of $A$. minutissimum has been observed and described by Geitler (1932) (using the synonymous species name Achnanthes minutissima). Auxosporulation was not directly observed in our cultures. Furthermore, the cultures can be considered as clonal, making sexual reproduction only possible if the diatoms are homothallic or capable for automixis. Both processes were found in pennate diatoms but represent rather exceptional processes in this group (Chepurnov et al. 2004). However, if auxosporulation would have occurred, conspicuously larger cells should have been observed at least occasionally in $A$. minutissimum, since cell length distribution of the culture was observed throughout the experimental duration. After 325 days of cultivation, the average length of xenic A. minutissimum indeed increased to $15.9 \pm$ $0.82 \mu \mathrm{m}$. According to Geitler (1932), $25 \mu \mathrm{m}$ is the maximal cell length of $A$. minutissima, while initial cells of this diatom in culture were reported to be smaller with $16.5 \mu \mathrm{m}$ (Locker 1950). This could be a hint that the length of the initial cell observed in environmental samples is not achieved under artificial conditions. However, A. minutissimum represents a species complex (Potapova \& Hamilton 2007) and it is nearly impossible to clarify whether Geitler and Locker used the same species. Locker (1950) observed that auxosporulation of A. minutissima occurred again after 15 months, while Byllaardt and Cyr (2011) noticed that cell reproduction of $A$. minutissimum in situ takes place with incidental auxosporulation occurring in spring. We did not observe periodic cell enlargement even after further cultivation for nearly one and a half year, possibly due to a lack of additional stimulating triggers in our comparatively constant cultivation conditions without annual changes in light and temperature compared to the study of Locker (1950). We therefore cannot exclude that 
bacteria might be involved in sexual reproduction and thus preserve cell lengths in case of $A$. minutissimum and $C$. affiniformis even if we do not consider this to be likely.

Other mechanisms that affect cell size of diatoms like vegetative cell enlargement (von Stosch 1965), vegetative auxosporulation (Nagai et al. 1995; Nagai \& Imai 1997; Sabbe et al. 2004), apomixis (Chepurnov et al. 2004) or abrupt cell size reduction (Locker 1950; von Stosch 1965; Chepurnov \& Mann 1997; Chepurnov et al. 2004) could also not be ruled out as possible explanation for the cell size differences observed in this study as bacteria may possibly serve as an additional external trigger for one of these mechanisms.

Another possible explanation for the differences in cell length between xenic and axenic diatom cultures could be the complex cell wall synthesis of diatoms. Silica biomineralization in diatoms strongly depends on long-chain polyamines (LCPA) (Kröger \& Poulsen 2008). Synthesis of a single molecule of LCPA with 20 methylated aminopropyl units consumes 40 molecules of $S$-adenosylmethionine, which is a derivate of the amino acid methionine (Michael 2011). The vitamin $B_{12}$ dependent methionine synthase may play an important role in the synthesis of the LCPA precursor methionine. This suggests that species with siliceous cell walls may have higher methionine requirements compared to the species that do not build siliceous cell walls. It was shown for algae from various groups that bacteria supplement vitamin $B_{12}$ to the algae (Croft et al. 2005). Possibly, the addition of vitamin $B_{12}$ into the medium was not enough for the synthesis of a sufficient amount of methionine during the cell wall synthesis in the axenic culture, while in the xenic culture bacteria might supply additional amounts of vitamin $B_{12}$.

In this study we showed that the presence of bacteria is important for morphology and size preservation of some diatoms and hence for healthy and stable long-term cultures. The extent of this effect apparently differs from species to species, as we found largest length differences between xenic and axenic states in A. minutissimum and $C$. affiniformis cultures and smaller differences in the case of $N$. palea. Our findings can be exploited for the long-term maintenance of diatom cultures and we recommend the storage of xenic diatom cultures for backup, from which axenic cultures can be repeatedly purified. Furthermore, we found that cultivation on solid medium may enhance the size diminution process of $A$. minutissimum cells. Apart from fundamental insights into the influence of bacteria on diatoms, our results may also help to optimize conditions for the stable long-term cultivation of diatoms. In the long-term, the identification of putative bacterial molecules that facilitate cell size maintenance of diatoms will be extremely valuable for keeping axenic diatom cultures stable even in the absence of bacteria.

\section{ACKNOWLEDGMENTS}

The authors thank Julia Rottberger for fruitful discussions and the Konstanz Research School Chemical Biology (GSC 218) as well as the University of Konstanz for financial support.

\section{REFERENCES}

Bates, S. S., Douglas, D. J., Doucette, G. J. and Léger, C. 1995. Enhancement of domoic acid production by reintroducing bacteria to axenic cultures of the diatom Pseudonitzschia multiseries. Nat. Toxins 3: 428-35.

Bruckner, C. G., Bahulikar, R., Rahalkar, M., Schink, B. and Kroth, P. G. 2008. Bacteria associated with benthic diatoms from Lake Constance: phylogeny and influences on diatom growth and secretion of extracellular polymeric substances. Appl. Environ. Microbiol. 74: 7740-9.

Buhmann, M. T., Day, J. G. and Kroth, P. G. 2013. Postcryopreservation viability of the benthic freshwater diatom Planothidium frequentissimum depends on light levels. Cryobiology 67: 23-9.

Byllaardt, J. V. and Cyr, H. 2011. Does a warmer lake mean smaller benthic algae? Evidence against the importance of temperature-size relationships in natural systems. Oikos 120: 162-9.

Chepurnov, V. A. and Mann, D. G. 1997. Variation in the sexual behaviour of natural clones of Achnanthes longipes (Bacillariophyta). Eur. J. Phycol. 32: 147-54.

Chepurnov, V. A., Mann, D. G., Sabbe, K. and Vyverman, W. 2004. Experimental studies on sexual reproduction in diatoms. Int. Rev. Cytol. 237: 91-154.

Croft, M. T., Lawrence, A. D., Raux-Deery, E., Warren, M. J. and Smith, A. G. 2005. Algae acquire vitamin $B_{12}$ through a symbiotic relationship with bacteria. Nature 438: 90-3.

Drebes, G. 1977. Sexuality. In Werner, D. (Ed.) The Biology of Diatoms. Botanical Monograph vol. 13. Blackwell Scientific Publications, Oxford, pp. 250-83.

European Committee for Standardization. 2003. Wasserbeschaffenheit - Leitfaden zur Probenahme und Probenaufbereitung von benthischen Kieselalgen in Fließgewässern Österreichisches Normungsinstitut, Vienna; Europäische Norm EN 13946.

Geitler, L. 1928. Copulation und Geschlechtsverteilung bei einer Nitzschia-Art. Arch. Protistenk. 61: 419-42.

Geitler, L. 1932. Der Formwechsel der pennaten Diatomeen (Kieselalgen). Arch. Protistenk. 78: 1-226.

Grossart, H. P., Czub, G. and Simon, M. 2006. Algae-bacteria interactions and their effects on aggregation and organic matter flux in the sea. Environ. Microbiol. 8: 1074-84.

Hünken, M., Harder, J. and Kirst, G. O. 2008. Epiphytic bacteria on the Antarctic ice diatom Amphiprora 
kufferathii Manguin cleave hydrogen peroxide produced during algal photosynthesis. Plant Biol. 10: 519-26.

Jeffrey, S. W. and Humphrey, G. F. 1975. New spectrophotometric equations for determining chlorophylls $a, b$, $c 1$ and $c 2$ in higher plants, algae and natural phytoplankton. Biochem. Physiol. Pflanzen. 167: 191-4.

Kaczmarska, I., Ehrman, J. M., Bates, S. S., Green, D. H., Léger, C. and Harris, J. 2005. Diversity and distribution of epibiotic bacteria on Pseudo-nitzschia multiseries (Bacillariophyceae) in culture, and comparison with those on diatoms in native seawater. Harmful Algae 4: 72541.

Kang, Y. H., Jung, S. W., Jo, S. H. and Han, M. S. 2011. Field assessment of the potential of algicidal bacteria against diatom blooms. Biocontrol Sci. Technol. 21: 969-84.

Kobayashi, K., Takata, Y. and Kodama, M. 2009. Direct contact between Pseudo-nitzschia multiseries and bacteria is necessary for the diatom to produce a high level of domoic acid. Fisheries Sci. 75: 771-6.

Krammer, K. 2002. Diatoms of Europe, Cymbella, Vol. 3. A.R.G. Gantner Verlag K.G., Liechtenstein, Ruggell.

Krammer, K. and Lange-Bertalot, H. 1986. Süßwasserflora von Mitteleuropa, Naviculaceae, Vol. 02/1. Gustav Fischer Verlag, Stuttgart.

Krammer, K. and Lange-Bertalot, H. 1988. Süßwasserflora von Mitteleuropa, Bacillariaceae, Epithemiaceae, Surirellaceae, Vol. 02/2. Gustav Fischer Verlag, Stuttgart.

Krammer, K. and Lange-Bertalot, H. 1991. Süßwasserflora von Mitteleuropa, Bacillariophyceae. Achnanthaceae. Kritische Ergänzungen zu Navicula (Lineolatae) und Gomphonema, Vol. 02/4. Gustav Fischer Verlag, Stuttgart.

Kröger, N. and Poulsen, N. 2008. Diatoms - from cell wall biogenesis to nanotechnology. Annu. Rev. Genet. 42: 83-107.

Lewin, J. C., Lewin, R. and Philpott, D. 1958. Observations on Phaeodactylum tricornutum. J. Gen. Microbiol. 18: 41826.

Locker, F. 1950. Beiträge zur Kenntnis des Formwechsels der Diatomeen an Hand von Kulturversuchen. Oesterreich. Bot. Zeitschr. 97: 322-32.

MacDonald, J. D. 1869. On the structure of the Diatomaceous frustule, and its genetic cycle. Ann. Mag. Nat. Hist. 3 $1-8$.

McLellan, M. 1989. Cryopreservation of diatoms. Diatom Res. 4: 301-18.

Mann, D. G. 2011. Size and sex. In Seckbach, J. and Kociolek, J. P. (Eds) The Diatom World, Vol. 19. Springer, Dordrecht, pp. 145-66.

Marshall, K., Joint, I., Callow, M. E. and Callow, J. A. 2006. Effect of marine bacterial isolates on the growth and morphology of axenic plantlets of the green alga Ulva linza. Microb. Ecol. 52: 302-10.

Martino, A. D., Meichenin, A., Shi, J., Pan, K. and Bowler, C. 2007. Genetic and phenotypic characterization of Phaeodactylum tricornutum (Bacillariophyceae) accessions. J. Phycol. 43: 992-1009.
Medlin, L., Elwood, H. J., Stickel, S. and Sogin, M. L. 1988. The characterization of enzymatically amplified eukaryotic 16S-like rRNA-coding regions. Gene 71: 491-9.

Michael, A. J. 2011. Molecular machines encoded by bacterially-derived multi-domain gene fusions that potentially synthesize, $\mathrm{N}$-methylate and transfer long chain polyamines in diatoms. FEBS Lett. 585: 2627-34.

Mitsutani, A., Yamasaki, I., Kitaguchi, H., Kato, J., Ueno, S. and Ishida, Y. 2001. Analysis of algicidal proteins of a diatom-lytic marine bacterium Pseudoalteromonas sp. strain A25 by two-dimensional electrophoresis. Phycologia 40: 286-91.

Murray, M. G. and Thompson, W. F. 1980. Rapid isolation of high molecular weight plant DNA. Nucl. Acid. Res. 8: 4321-6.

Nagai, S. and Imai, I. 1997. The effect of irradiance and irradiation time on the size of initial cells in vegetative cell enlargement of Coscinodiscus wailesii (Centrales, Bacillariophyceae) in culture. Phycol. Res. 45: 117-21.

Nagai, S. and Imai, I. 1998. Enumeration of bacteria in seawater and sediment from the Seto Inland Sea of Japan that promote sperm formation in Coscinodiscus wailesii (Bacillariophyceae). Phycologia 37: 363-8.

Nagai, S., Hori, Y., Manabe, T. and Imai, I. 1994. Promotion of sperm formation of a giant diatom Coscinodiscus wailesii Gran by a marine bacterium. Fisheries Sci. 60: 625-6.

Nagai, S., Hori, Y., Manabe, T. and Imai, I. 1995. Restoration of cell size by vegetative cell enlargement in Coscinodiscus wailesii (Bacillariophyceae). Phycologia 34: 533-5.

Nagai, S., Imai, I., Yamauchi, K. and Manabe, T. 1999. Induction of sexuality in the diatom Coscinodiscus wailesii Gran by a marine bacterium Alcaligenes sp. in culture. In Mayama, S., Idei, M. and Koizumi, I. (Eds) Proceedings of the Fourteenth International Diatom Symposium. Koeltz Scientific Books, Koenigstein, pp. 197-212.

Pfitzer, E. 1871. Untersuchungen über Bau und Entwicklung der Bacillariaceen (Diatomaceen). Bot. Abh. aus dem Gebiet der Morphologie und Physiologie 1: 1-189

Potapova, M. and Hamilton, P. B. 2007. Morphological and ecological variation within the Achnanthidium minutissimum (Bacillariophyceae) species complex. J. Phycol. 43: 561-75.

R Development Core Team (home page on the internet). 2011. R: A Language and Environment for Statistical Computing. R Foundation for Statistical Computing, Vienna, Austria. ISBN 3-900051-07-0 [cited 18 March 2014]. Available from: http://www.R-project.org/

Sabbe, K., Chepurnov, V. A., Vyverman, W. and Mann, D. G. 2004. Apomixis in Achnanthes (Bacillariophyceae); Development of a model system for diatom reproductive biology. Eur. J. Phycol. 39: 327-41.

Sapp, M., Wichels, A. and Gerdts, G. 2007. Impacts of cultivation of marine diatoms on the associated bacterial community. Appl. Environ. Microbiol. 73: 3117-20. 
Schäfer, H., Abbas, B., Witte, H. and Muyzer, G. 2002. Genetic diversity of 'satellite' bacteria present in cultures of marine diatoms. FEMS Microbiol. Ecol. 42: 25-35.

Trobajo, R., Mann, D. G., Chepurnov, V. A., Clavero, E. and Cox, E. J. 2006. Taxonomy, life cycle, and auxosporulation of Nitzschia fonticola (Bacillariophyta). J. Phycol. 42: 135372.

von Stosch, H. 1965. Manipulierung der Zellgrösse von Diatomeen im Experiment. Phycologia 5: 21-44.

Wiedling, S. 1948. Contributions to the knowledge of the vegetative propagation of the diatoms (Beiträge zur Kenntnis der vegetativen Vermehrung der Diatomeen). Bot. Not. 1948: 322-54.
Windler, M., Gruber, A. and Kroth, P. G. 2012. Purification of benthic diatoms from associated bacteria using the antibiotic imipenem. Endocyt. Cell. Res. 22: 62-5.

\section{SUPPORTING INFORMATION}

Additional Supporting Information may be found in the online version of this article at the publisher's web-site:

Appendix S1. Influence of bacteria on cell size development and morphology of cultivated diatoms. 